\title{
Disrupting Conventional Law Firm Business Models using Document Assembly
}

\author{
DARryl R. MOUNTAIN ${ }^{1}$
}

\begin{abstract}
Document assembly software is a technology that is fundamental to disrupting law firms. This article uses the framework set out by Clayton Christensen in The Innovator's Dilemma and subsequent books to examine the range of business models that use document assembly software, from those that are sustaining in relation to law firms to those that are disruptive in relation to law firms. It looks at three barriers that slow down the pace of disruption: a shortage of the right people, rules against unauthorised practice, and inadequate capitalisation of law firms. These barriers will be overcome on a piecemeal basis as disruptive forces advance and undercut the billable hour.
\end{abstract}

Keywords: artificial intelligence, billable hour, capitalisation of law firms, document assembly, disruptive innovations, disruptive technologies, future of law, innovator's dilemma, law firm management, legal web advisors, online legal services, unauthorised practice.

\section{Introduction}

Two big ideas that are relevant to the legal technology field made their first appearance in the 1990s. The first, in Richard Susskind's book The

\footnotetext{
${ }^{1}$ L.L.M. (LSE), Barrister \& Solicitor and active member of the American Bar Association eLawyering Task Force, 512 East 12 ${ }^{\text {th }}$ Street, North Vancouver, BC V7L 2K4 Canada. Telephone 01.604.771.9424. E-mail: darryl.mountain@ontago.com
} 
Future of $L a w,{ }^{2}$ was that law is moving from an advisory service to an information service and only the specialists will survive. The second, in Clayton Christensen's book The Innovator's Dilemma, ${ }^{3}$ was that the disruptors in a given industry eventually will take over most of the market from the incumbents. These ideas mesh very well and are proving to be durable. More and more disruptors are arising in areas such as alternative dispute resolution, e-learning based risk reduction, competitive sourcing of legal work, outsourcing and open sourcing, and legal information services. Given the relative lack of concentration in the legal services market ${ }^{4}$ and the 40 percent margins that Am Law 100 firms command (at least twice that of America's largest publicly traded corporations), ${ }^{5}$ it would appear that law is an area that is ripe for disruption.

If there is one technology that is fundamental to disruptive innovations in law, it is document assembly. In a recent speech marking the 10-year anniversary of The Future of Law, Richard Susskind stated the following:

I cannot help but feel that document assembly technology is and will remain forever, as it were, a fundamental technology. If one looks at the heart of legal work, it's about the production of documents and document assembly is an enabling tool that automates and streamlines that process ... Document assembly will be vital at the automation and systematisation phase and also vital for packaging and commoditising. ${ }^{6}$

This article will use Christensen's theory of disruptive innovations to analyze the different business models that use document assembly software and will highlight some of the obstacles to widespread adoption of these business models that exist.

\section{The Innovator's Dilemma}

The theory of disruptive innovations is based on the fact that companies innovate faster than peoples' lives change, which leads to overshot consumers (consumers for whom existing products or services are more than good enough) and opens the door to 'good enough' solutions for low end consumers and non-consumers. These solutions are not as good as current solutions but they are usually cheaper and more convenient. Examples of disruptive innovations that have taken over their respective

\footnotetext{
${ }^{2}$ Susskind, The Future of Law: Facing the Challenges of Information Technology (Clarendon Press: Oxford 1996).

${ }^{3}$ Christensen, The Innovator's Dilemma: When New Technologies Cause Great Firms to Fail (Harvard Business School Press: Boston 1997).

${ }^{4}$ Galanter and Palay, 'The Many Futures of the Big Law Firm', South Carolina Law Review 45, p. 905 at 913 .

${ }^{5}$ Innosight LLC, ‘eLawForum: Transforming Legal Services', 21 January 2003 at 2.

${ }^{6}$ Susskind, 'The Next Ten Years', Society for Computers and Law 2006 Annual Lecture, 6 March 2006.
} 
markets are hydraulic excavators (versus mechanical shovels) ${ }^{7}$ and online trading versus broker-based trading. ${ }^{8}$

Within the legal industry context, a disruptive innovation is a low-end commoditisation that marginalises the conventional law firm business model. A sustaining innovation, by contrast, is something that enables law firms to improve what they already do, which is to provide legal advice to clients and generate billable hours and income for their partners.

Contrary to popular misconception, disruptive innovations do not offer dramatically improved performance (these are called radical sustaining innovations and lawyer use of the Blackberry is a good example). Instead, what they offer is a new value proposition.

The value proposition of a typical law firm is based on full and customised service, limited availability, reactivity, and unpredictable and high fees based on time spent.

Disruptive services offer a new value proposition based on self service that is not fully customised but 'good enough', 24 x 7 availability, proactive risk reduction, and low fixed fees earned while the lawyer sleeps. ${ }^{9}$

\section{The Legal Document Assembly Industry}

Legal document assembly software was pioneered in the late 1970s. The basic functions are to replace the cumbersome manual filling in of repetitive documents with template-based systems where the user answers software-driven interview questions. The information collected then populates the document to form a good first draft.

In the legal context, document assembly software began as a tool that lawyers themselves used to create their own documents. That use continues and has become increasingly sophisticated. In the past, companies tended to create their own document assembly tools in-house, but today there are many off-the-shelf packages available. The industry has seven serious players. The leading products are (in alphabetical order): D3, DealBuilder, Exari, GhostFill, HotDocs, Rapidocs, and QShift. ${ }^{10}$ They fill different niches and offer a range of capabilities from clause management to open standards to e-commerce optimisation to contract process automation.

At the low end, document assembly software is being coupled with content, packaged, and sold to law firms as ready-to-use precedents. At the

\footnotetext{
${ }^{7}$ Supra note 3 at 69.

${ }^{8}$ Supra note 3 at 57.

${ }^{9}$ Mountain, 'Could new technologies cause great law firms to fail?', 2001 (1) The Journal of Information, Law and Technology (JILT).

${ }^{10}$ Lauritsen, 'Fall in line with document assembly: applications to change the way you practice', Law Office Computing, February/March 2006, p. 70 at 74.
} 
high end, it is evolving into contract process automation software that manages the contract life cycle from data capture to the signature stage.

The invention of the Web browser marked the birth of business models that are disruptive in relation to law firms. These new business models provide solutions to legal problems without the involvement of a lawyer practising in a conventional law firm.

Richard Granat, co-chief of the American Bar Association's eLawyering group, notes that the increasing reach of the Web makes it more economical to automate a given document. ${ }^{11}$ A model home renovation contract may not be worth automating if the lawyer who created it uses it twice a year. But if that same lawyer puts the contract on the Web within the reach of millions of people, its use likely will escalate, justifying automation. ${ }^{12}$

Indeed, document assembly has been adopted much more readily with respect to disruptive applications than for sustaining applications. Many established law firms have opted not to use document assembly software. Thirty-one percent of U.S. lawyers use generic document assembly software and 11 percent use specialized document assembly software (eg family law or contracts). ${ }^{13}$ However, many forms of law-related disruption make use of document assembly software.

\section{The Evolution of Christensen's Thinking}

Before we analyze the document assembly industry using Christensen's model, let's examine how his thinking has been refined in his two subsequent books, The Innovator's Solution and Seeing What's Next.

\subsection{Disruptive Innovations}

One of the key ways in which Christensen's thinking has evolved is evidenced by a change in terminology. Christensen has replaced the term 'disruptive technologies' with 'disruptive innovations'. This highlights the fact that disruption is a relative term: it is the business model that is disruptive and not the technology. For example, the Internet was sustaining to Dell's mail order strategy because selling over the Web is an extension of selling by mail order. However, the Internet was disruptive to Compaq's retail channel strategy because it facilitated direct selling. Same technology; different effect. ${ }^{14}$

\footnotetext{
${ }^{11}$ Granat, Lauritsen and Mountain, 'Will Document Automation Disrupt the Legal Profession? A roundtable discussion sponsored by the ABA's eLawyering Task Force', Loew's Hotel Philadelphia, 22 October 2005.

${ }^{12}$ The small but omnipresent level of demand for a particular item such as an obscure song or document sold online has been described as the statistical "long tail" in Anderson, The Long Tail: Why the Future of Business is Selling Less of More (Hyperion: New York 2006).

${ }^{13}$ American Bar Association Legal Technology Resource Center, '2004-2005 American Bar Association Legal Technology Survey Report: Law Office Technology'.

${ }^{14}$ Christensen and Raynor, The Innovator's Solution: Creating and Sustaining Successful Growth (Harvard Business School Press: Boston 2003) at 193.
} 
This change in thinking is helpful because it allows us to shift our focus from trying to determine whether a given technology such as the Internet is disruptive to examining the different possible business models for that technology. As we will see, document assembly as a technology is neutral. It is the business models that employ it that are capable of being disruptive or sustaining.

\subsection{A process, not an event}

One could get the mistaken impression from The Innovator's Dilemma that disruption proceeds swiftly and surely as incumbents fail and are replaced by newcomers. However, in The Innovator's Solution, Christensen specifies that disruption is a process, not an event. It needs a long runway to succeed. For example, cardiologists doing angioplasty have been disrupting heart surgeons doing cardiac bypasses for two decades ${ }^{15}$ During this time period, the stents and techniques used in angioplasty have continued to improve. However, it is only since 1997 that the number of cardiac bypasses performed in the United States has begun to decline. ${ }^{16}$ Characterising disruption as a process and not as an event shows that law firms do not have to fail immediately for the disruption to be working.

We are at a very early stage in the decades-long disruption of law firms. Many of the disruptive business models will be Web-based. As Richard Granat has stated, Google has shown that the Internet is a platform from which to launch an endless array of 'good enough' services. ${ }^{17}$ For example, Google news alerts are disrupting news clipping services that have been around for decades. Anyone who wants to monitor the news on a particular topic need only sign up for a Google news alert for particular keywords and they will receive an e-mail with a link every time new material containing those keywords is disseminated on the Internet.

We would expect the disruption of law firms to begin in the consumer market and to work its way upward gradually. It is the small, local firms that already may have lost their battle against disruptive forces. Those at the high end of the market will feel the effects last.

\subsection{Segmenting by Jobs to be Done}

Another development of the subsequent books has been the introduction of the 'jobs to be done' perspective. Rather than segmenting the market along traditional lines, Christensen recommends that you analyze it through a 'jobs to be done' perspective. He gives the example of a simple milkshake, which can play several different roles in people's lives. For

\footnotetext{
${ }^{15}$ Ibid at 109.

${ }^{16}$ Christensen, Anthony and Roth, Seeing What's Next: Using the Theories of Innovation to Predict Industry Change (Harvard Business School Press: Boston 2004) at 186.

${ }^{17}$ Supra note 11.
} 
harried parents, the job to be done is to placate their children, while for commuters, the job to be done is to entertain them during a long, boring commute. When you are aware of these different jobs to be done, you can tailor the milkshake for the children by lowering its viscosity to allow for quick consumption by children. You can tailor it for commuters by swirling in chunks of fruit for entertainment value. ${ }^{18}$

With law, the job to be done varies tremendously from player to player. In general, it is probably fair to say that the job of law is to manage risk and to obtain peace of mind. Indeed, the less risk consumers perceive, the more attractive they find the various 'do it yourself' options.

\subsection{Provider-level and point of care disruptions}

In Seeing What's Next, Christensen describes provider-level disruptions in the medical field. ${ }^{19}$ The legal field has a similar structure: specialists and sub-specialists in large firms occupy the top of the pyramid, followed by small firms, sole practitioners, in-house lawyers, notaries, paralegals, legal process outsourcing (LPO) companies, and self-help remedies.

Point-of care disruptions also exist in law. The law office is being disrupted by closing centers for real estate transactions, mobile lawyers who visit bank branches, and Internet browsers and call centres that reach people at home.

Many innovative business models combine provider-level and point of care disruptions. Going back to our previous example, the cardiologist who does the angioplasty at a cardiac care clinic disrupts the heart surgeon who performs the bypass in an operating room.

As we shall see, some of the more disruptive business models that use document assembly also combine provider level and point of care disruptions in that they avoid the use of lawyers and take place outside law offices.

\section{Business Models for Document Assembly in Law}

There is a continuum of business models for document assembly, both in theory and in practice, that range from the sustaining to the disruptive. I have identified six, of which four are currently in use and two are merely theoretical at this point.

The continuum corresponds roughly to Richard Susskind's latest model introduced in his recent lecture to the Society for Computers and Law. ${ }^{20}$ That model begins with bespoke (customised) services on the left, followed by standardisation, systematisation, packaging for external use,

\footnotetext{
${ }^{18}$ Supra note 14 at 75.

${ }^{19}$ Supra note 16 at 185 .

${ }^{20}$ Supra note 6.
} 
and commoditisation. In both models, clients are increasingly 'pulling to the right', demanding more commoditised forms of legal services.

\subsection{Law Firms with hourly billing}

Most law firms operate with what Innosight (a consulting firm founded by Christensen) calls the 'sole-source/billable hour/cost-plus' business model. ${ }^{21}$ For firms that bill by the hour, document assembly is a radical sustaining innovation that dramatically improves performance. A lawyer who uses document assembly can produce first drafts of documents in a fraction of the time it otherwise would take.

Many lawyers who bill by the hour are reluctant to become too efficient. As leading document assembly expert Marc Lauritsen has stated, 'why spend money to get work done faster when you charge for your time?"22 One reported response to a document assembly proposal was, 'What are you, a communist?. ${ }^{23}$ Lawyers don't perceive a payback for investing in a technology that doesn't appear to have the potential to increase their hourly rates or their number of billable hours.

In fact, lawyers who become more efficient due to technology can raise their hourly rates, so long as they are able to justify this increase clearly to their clients. Blair Janis is a Salt Lake City legal technologist whose firm, Ballard Spahr, uses document assembly in conjunction with hourly billing. He describes one benefit of automating documents within the billable hour framework: 'individual clients pay less than they would have without the automation (fewer hours for that client), but the lawyer continues to bill the same number of hours overall at a higher rate than before (getting more work done for more clients in the same amount of time it took without the automation). ${ }^{, 24}$

Lawyers who succeed in increasing their profitability through efficiency gains have trouble getting their efforts recognised in partnerships that value billable hours above all else. Law firms typically use billable hours to determine who gets associate bonuses, who gets promoted to partner and which partners get the most compensation. Efficiency concerns are secondary.

Part of the reason for lawyer hesitation to combine document assembly 'power tools' with hourly billing has been the lack of client pressure. For example, home renovation contractors also use power tools and also charge by the hour. When a contractor needs to cut several pieces of wood, however, he uses an electric saw, not a handsaw. The difference is that homeowners are aware of the existence of power tools and insist on their use but many legal consumers do not appear to be as well-informed. ${ }^{25}$

\footnotetext{
${ }^{21}$ Supra note 5 at 1.

${ }^{22}$ Lauritsen, 'Profit more by billing less: technology that saves time and fattens the bottom line', TechnoLawyer, 21 February 2006.

${ }^{23}$ Lauritsen, 'It's About Time', Law Practice Management, April 2002, p. 26 at 27.

${ }^{24}$ Supra note 22.

${ }^{25}$ There are exceptions. See Owen, 'The Tech Evolution: Change or Die', Law.com, 4 January 2005.
} 
The risk of combining document assembly with hourly billing is that competitors will arise with new business models that allow them to charge by the job rather than by the hour. These competitors will make money under the price umbrella created by the firms who bill by the hour. ${ }^{26}$

\subsection{Law Firms with alternative billing}

We leave the cost-plus revenue model behind at this juncture. No longer do we assess the value of a document based on the number of hours of time put into its creation at the author's billable rate. Instead, documents are priced based on their value to the user.

With alternative billing, the lawyer assembles his or her own documents but the law firm bills the client other than by the hour. A law firm with sophisticated document assembly capabilities can undercut its competitors on price and make up the difference by turning around huge volumes of documents. Or it can make accurate fixed price bids for deals based on the ability to produce almost instant first drafts of documents. For example, auction models such as eLawForum <www.elawforum.com $>$ source legal work for large corporations through a competitive bidding process. As these models increase in popularity, the most efficient law firms will be able to bid the lowest, knowing that their technology infrastructure still allows them to make money. ${ }^{27}$

Two Australian firms offer residential conveyancing on a low fixed fee basis without any additional charges for disbursements. Queensland's KRG Conveyancing Centre <www.krg.com.au $>$ is the second largest conveyancing firm in Australia ${ }^{28}$ and a heavy user of document assembly tools. ECommLegal Pty Ltd. <www.ecommlegal.com.au $>$ is an incorporated legal practice backed by the Commonwealth Bank and blue chip law firm Clayton Utz. In addition to fixed-fee conveyancing, it offers access to discounted mortgage rates for conveyancing clients and wills on a do-it yourself basis or with a customised lawyer option. HammondsDirect <www.hammondsdirect.com> operates a similar type of service in the UK.

Dow and Lapuerta have made the following comment with respect to the use of leverage in conveyancing:

As one lawyer put it to us, the entire conveyancing system for the UK only needs one lawyer to operate it - this person would be responsible for approving the design and operation of a large IT system. This is an exaggeration, but everybody seems to agree that conveyancing, in the vast majority of instances, can be largely commoditised. ${ }^{29}$

\footnotetext{
${ }^{26}$ Personal e-mail from Brad Gambill of Innosight LLC, 23 April 2006.

${ }^{27}$ Richard Susskind doesn't think that the auction models will work while they are simply appended to customised services. Supra note 6.

${ }^{28}$ Personal e-mail from Simon Lewis of the Sinch Group, 13 February 2006.

${ }^{29}$ Dow and Lapuerta, 'The Benefits of Multiple Ownership Models in Legal Services', July 2005, at 9.
} 
One of Canada's largest law firms, Gowlings, also uses alternative billing. The Gowlings Recovery Service Group uses document assembly software to completely automate the mortgage recovery and debt collection process. The fees are fixed and the mortgage enforcement lawyers involved do not keep track of their time. ${ }^{30}$

\subsection{Hybrid of self-help documents and legal advice}

At this critical point in the continuum, we move to the disruptive side of the equation because it is no longer the lawyer who generates the document; it is the client.

Tim Allen, CEO of Business Integrity, whose product is DealBuilder, likes to ask potential clients, 'What is the difference between Madonna and Mozart?' It has nothing to do with who had the greatest musical genius. $^{31}$

It is beyond dispute that Mozart created great content. However, Mozart played for his patron a series of one-off performances and he often received no payment for his work. He played in front of, at most, a few thousand people in his lifetime.

Madonna, the Queen of Pop Music, records her music and licenses it out to millions of people. Warner Brothers has said that she has sold more than 200 million albums. ${ }^{32}$ Her estimated net worth is in excess of $\$ 850$ million. ${ }^{33}$ Her hourly rate (should one wish to calculate it) would be phenomenal.

Most law firms are locked into the Mozart model of distributing their content at an hourly rate. A few firms are starting to realise that they could make more money by licensing their content the way Madonna does.

In the early part of the decade, Linklaters was able to make gains on its rivals in the syndicated loan market when it introduced Linklaters Blue Flag. Blue Flag allowed banks to generate their own term sheets for free via extranet. Once the data was input into the term sheets, Linklaters had the ability to produce an instant first draft of all the deal documents. This capability made for a compelling reason why the bank should use Linklaters for that particular deal. Blue Flag has evolved into a suite of online products covering everything from derivatives to pensions and shareholding disclosure.

Brown and Partners is an Australian law firm with a classic new market disruption model that attracts nonconsumers, people who otherwise would not obtain legal advice but who simply would do nothing. Brown and Partners focuses on debt collection, but it does so in a disruptive fashion.

\footnotetext{
${ }^{30}$ Supra note 23 at 30.

${ }^{31}$ Supra note 11.

${ }^{32}$ Warner Bros. Records, “Confessions On A Dance Floor': New Madonna Album Re-Invents Dance Music for a New Generation', October 12, 2005.

${ }^{33}$ http://www.absolutemadonna.com/achievements/
} 
Small businesspeople who are owed money but who are uncertain how to proceed are drawn to the website by radio ads and by a weekly radio program on a popular Sydney talk station.

On the website $<$ www.brownandpartners.com.au $>$ is an automated debt collection service that is free to the user so long as the debtor doesn't file a defence (document processing charges and court fees apply). Like the original Linklaters model, the online service establishes an initial rapport with the client and there is a compelling reason to use the firm if the debtor files a defence or if other complications arise. Since all documents are generated on a self-serve basis by the consumer and are not intended to be relied upon as legal advice, Brown and Partners presumably does not have to hire lawyers to review the documents.

Corporate law departments disrupt law firms by bringing routine work in-house, 'making' rather than 'buying' and competing with their suppliers. ${ }^{34}$ In the law department environment, document assembly uses built-in guidance and safeguards to manage the legal risk associated with producing documents in-house. For example, Cisco uses a 'trap door' model that allows its salespeople to produce nondisclosure agreements.

Picture a document as a flat surface with trap doors leading to in-house lawyers hidden below. An employee is generating a document in a question-and-answer dialog session powered by document assembly software. If all questions are answered in a legally 'safe' fashion, then the document is generated immediately. However, if the person answers a particular question in a fashion that requires the inclusion of a nonstandard clause, then he or she trips a trap door and the document goes to the law department for review. This system mitigates against the risks of employees using outdated versions of documents, making unauthorised changes, or involving the legal department too late in the deal process.

With respect to the 'jobs to be done' framework, this example illustrates the fact that a firm may choose to use document assembly for particular jobs but won't necessarily use it for other jobs. It is only a narrow range of high volume agreements within any given company that could be made subject to the 'trap door' treatment.

Ron Friedmann of Prism Legal Consulting maintains a list of law firm online services on his website. ${ }^{35}$ Many of these models are hybrids of selfhelp documents and legal advice. Some of the best known models are Allen \& Overy's newchange, ${ }^{36}$ Bryan Cave's eCave, ${ }^{37}$ Davis Polk's Global Collateral Project, and Blake Dawson Waldron's salt. ${ }^{38}$

\footnotetext{
${ }^{34}$ Supra note 5 at 3 .

${ }^{35}$ http://mywebpages.comcast.net/ronfriedmann/ExamplesLegalGuidanceOnTheWeb.htm

${ }_{36}$ http://www.allenovery.com/AOWEB/OnlineServices/OnlineServicesHome.aspx?contentTypeID=8\& prefLangID $=410$

${ }^{37}$ http://www.bryancave.com/practice/csgdetail.asp?csgID=999

${ }_{38} \underline{\mathrm{http}: / / \text { compliance.bdw.com/ }}$
} 


\subsection{Document assembly + outsourcing}

Legal process outsourcing ('LPO') has captured headlines within the past year as law firms and corporate law departments send increasingly sophisticated types of legal work abroad to be executed in places like India and New Zealand. The technology being used to process this work is still immature. Outsourcing by the law firm just sustains the law firm's business model, but outsourcing by the client corporate law department is disruptive to the law firms who otherwise would do the work.

In a typical LPO company such as OfficerTiger $<$ www.officetiger.com $>$ or Pangea3 <www.pangea3.com>, the commercial contracts team in Mumbai drafts contracts, beginning from a database of forms. These contracts are reviewed by U.S. lawyers before being sent to the client.

If the forms were available in document assembly format, the Mumbai lawyer would draft the contracts through an online interview process. In an extension of the trap door model, contracts could go through a channel requiring minimal review by the U.S. lawyer where the selections are 'safe' or could be flagged for further scrutiny where selections are not 'safe'. Eventually you could have a model where contracts are drafted inhouse in the United States, the Indian lawyer handles exceptions only, and the U.S. lawyer reviews the Indian lawyer's work.

This example illustrates the tradeoff between people and software and points out how one can easily disrupt the other. How could software disrupt the LPO business model? If document assembly software contained sufficient guidance that a person with no legal training could draft a document under most circumstances, then the exceptions handled by the Indian lawyer would become increasingly slim.

On the other hand, it is also possible for people-based business models to disrupt software-based business models. For example, it seems, anecdotally at least, that the availability of Indian call centre labour has led to the scaling back of research into phone-service software that uses voice recognition. ${ }^{39}$ Call centre workers and automated operators act both as complements and substitutes for each other, much like offshore labour and document assembly software. When one becomes significantly cheaper than the other, customers will switch.

In China Inc., Ted Fishman discusses the people-based disruption of software in the Chinese context:

In China, however, where the cost of programmers and code-tweakers is far lower, the cost of taking on a Linux-based system and maintaining it does not make it more expensive than Windows in the long run. The disruptive potential of China's low labor costs to the dominant software monopolies is real. If Chinese companies can assert an

\footnotetext{
${ }^{39}$ Saunders, 'Why you don't have a robot maid' Globe and Mail (Toronto), 11 February 2006, F3.
} 
advantage by migrating away from American and European software, American and European companies will have to find a way to assert similar savings. ${ }^{40}$

\subsection{Pure-play Disruption}

Christensen's theory predicts that disruption would start out in the consumer market, where there are many overshot clients who don't want to pay high hourly rates to get jobs done that have low associated dollar values. It would then work its way upwards. That appears to be happening. Most pureplay disruptors are currently focused on the consumer market, with a few exceptions.

The distribution of legal services through non-traditional outlets is sometimes known as 'Tesco Law'. Tesco operates a website < www.tescolegalstore.com $>$ from which it licenses documents to consumers. Tesco is expected to expand its legal presence as UK law firm investment requirements liberalise. The Royal Automobile Club is said to have similar ambitions. $^{41}$

Other interesting consumer models are We the People <www.wethepeopleusa.com $>$, legalZoom $<$ www.legalzoom.com $>$, and SmartLegalForms. com $<$ www.smartlegalforms.com $>$.

We The People is a document preparation company that has over 150 storefront locations in 31 states of the U.S. Interestingly, We the People has perhaps the highest revenues of any pureplay disruptor in the U.S., despite the fact that it relies more on retail-based innovation than technology-based innovation. ${ }^{42}$ Customers fill in a paper questionnaire and paralegals post data from that questionnaire to a desktop document assembly program. The completed document is returned to the store by e-mail for printing out and delivery to the customer. Granat attributes this success to a disruptive marketing strategy that uses the storefront retail interface. He explains,

Consumers have difficulty in processing text. The Internet is still primarily a text medium. This inability accounts for the present low utilisation rate. Consumers want solutions. They don't want to read self-help books. They don't want to understand complex instructions. A small portion of the consumer market can master the text to the point where they do not need the assistance of any one. But most

\footnotetext{
${ }^{40}$ Fishman, China Inc.: How the Rise of the Next Superpower Challenges America and the World (New York: Scribner) at 249.

${ }^{41}$ Brealey and Franks, 'The Organisational Structure of Legal Firms; a Discussion of the Recommendations of the 2004 Review of the Regulatory Framework for Legal Services in England and Wales', 13 July 2005 at 18.

${ }^{42}$ Although current revenues are undisclosed, Dollar Financial Corp. acquired the assets of We the People on March 7, 2005 for an aggregate purchase price of \$14.0M. See http://sec.gov/Archives/ edgar/data/1271625/000089322006001089/w20759e10vq.htm at p. 25.
} 
consumers want some human help to either solve their problem for them, or help them solve their problem. ${ }^{43}$

LegalZoom and SmartLegalForms.com do not have a physical presence: they license documents to consumers over the Internet and offer paralegal-based telephone support. The distinction between the two services is that LegalZoom offers legal document preparation services only, while SmartLegalForms.com offers both legal document preparation services and self-help document preparation. With legal document preparation services, a paralegal team either inputs data that comes in over the Internet into desktop document assembly software or reviews the data that the client has already input into web-based document assembly software. The self-help option allows the consumer to generate a document immediately, without assistance. LegalZoom is backed by O.J. Simpson's former 'dream team' lawyer, Robert Shapiro, while SmartLegalForms. com claims to license 12,000 documents per month. ${ }^{44}$

According to Susskind, legal risk management and compliance with regulations are top-of-mind for most in-house counsel. ${ }^{45}$ Hedge Op Compliance $<$ http://www.hedgeop.com $>$ is a New York-based company dedicated to helping hedge funds tackle legal compliance issues using Web and e-mail-based tools, leaving expensive Wall Street law firms out of the loop. It was set up in 2001 by a young Wall Street attorney who left his firm. The existence of such a business shows that even the large and powerful Wall Street law firms are not immune to the effects of commoditisation.

The first few pureplay disruptor models listed above are broad and shallow and tend to attract people who would not otherwise be using a lawyer. However, Hedge Op Compliance has developed a highly focused niche. It focuses on a narrow range of services that formerly was a "cash cow' for law firms and has replaced the customised approach used by these firms with a commoditised approach.

Finally, governments and nonprofit agencies occasionally become involved in the disruptive game. Another debt collection model is Money Claim Online $<$ www.moneyclaim.gov.uk $>$, the largest issuing county court in England and Wales. Money Claim Online allows individuals, organisations, or their legal representatives to pursue fixed money claims online, up to $£ 100,000$. Non-profit organisations such as National Public ADO (Automated Documents Online) <www.npado.org > and eJustice $<$ www.ejustice.org $>$ deliver free smart forms to low-income people and their advocates.

\footnotetext{
${ }^{43}$ Personal e-mail from Richard Granat, 6 April 2006.

${ }^{44}$ Supra note 11.

${ }^{45}$ Supra note 6.
} 
When governments and nonprofits automate processes like debt collection and incorporation, they improve access to justice for the consumer, sometimes at the expense of incumbent law firms and would-be-entrepreneurs.

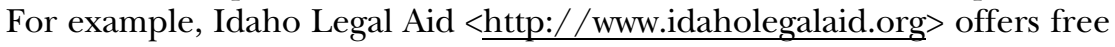
name changes that are available to anyone who goes to the website; there is no need to qualify as low income first. Illinois Legal Aid $<$ http://www. illinoislegalaid.org $>$ offers free online debt collection. These services have been attracting more middle-income users than low-income users. ${ }^{46}$ An incorporation service like incorporator.com.au <http:/ / www.incorporator. com.au $>$ is not needed for federal incorporations in Canada, which can be done online through a government website. ${ }^{47}$

Entrepreneurs also play a part in driving down the cost of legal information (as opposed to legal advice). One example is the free child support calculator available on $<$ www.alllaw.com $>$.

\subsection{Disruption with insurance component}

If law's job to be done is to obtain peace of mind then, in many circumstances, an acceptable substitute for a lawyer would appear to be an online document combined with insurance to cover the possibility of something going wrong with that document. It is not a perfect substitute because it doesn't replace the professional values of confidentiality, conflicts checking, and accountability that are associated with lawyers.

A major part of a lawyer's role is to perform an insurance function. To put it simply, lawyers can be sued if something goes wrong. For example, a lawyer who drafts a will negligently can be sued. People have used selfhelp will kits to create a will only to discover that the will didn't contemplate their particular fact situation, leaving them without recourse.

Consumers don't appear to recognise the need to reduce their risk using this insurance function. Many people think of estate planning as form-filling and regard consumer document preparation businesses as a perfect substitute for a lawyer.

No online document-plus-insurance model has yet been invented. Insurance exists in the background in the form of errors and omissions insurance to cover mistakes by the lawyer. However, the lawyer is required to analyze the facts and issues of each particular situation. Fact situations vary tremendously and the risk varies from one situation to the next. It would be difficult to replace the current system with one where insurance is in the foreground and where there is blanket coverage of the most common fact situations, with legal advice covering areas of exception only. But, as the existence of title insurance demonstrates,

\footnotetext{
${ }^{46}$ Janis, Granat and Colpoys, 'Ten Techniques to Exploit Latent Legal Markets' and Granat, Cameron and Subramanian, 'Partners and Promise in E-Lawyering', ABA TECHSHOW 2006, 20 April 2006.

${ }^{47}$ http://strategis.ic.gc.ca/cgi-bin/sc_mrksv/corpdir/corpFiling/register.cgi?lang=e.
} 
insurance can disrupt lawyers by insuring away the risk that a lawyer otherwise would minimise through the use of legal tools such as searches.

\section{Eliminating the Barriers}

There remain several important sources of friction against disruption, including the scarcity of people who are capable of developing disruptive models, inadequate capitalisation of law firms, and rules against unauthorised practice. These sources decrease the pace at which disruption proceeds and limit the types of disruption that are possible.

\subsection{Shortage of the right people}

Large law firms are typically partnerships that are engineered for high end performance and customised work. As discussed earlier, the typical Am Law 100 firm makes a 40 percent profit margin, at least twice that of America's largest publicly traded corporations. ${ }^{48}$ According to economic theory, these firms have a higher quality threshold in hiring than corporations.

The firm will hire new partners only if the result is to increase the average profits per partner. A corporation by contrast is interested in total profits and will bring in new staff as long as the marginal benefit exceeds the marginal cost. This difference in objectives results in a higher quality threshold for employment in partnerships and hence a higher quality product. ${ }^{49}$

Quality and revenue generation are further rewarded through 'eatwhat-you-kill' compensation systems.

This law firm obsession with quality and high margin work is precisely what holds them back from experimenting with disruptive business models.

The partnership model, based on committees and consensus, makes for conservative decision-making. Partners who have risen to the top by doing things the conventional way are not the sort of people who are going to think differently. Partners compensated on an 'eat-what-you-kill' basis have an incentive to hoard information from other partners. Many innovative people who could make a difference get squeezed out early in the partnership race because they don't fit into the prevailing culture. ${ }^{50}$

A few rebels occasionally slip through, and it is these rebels who have initiated the progress that has been made. In a recent London Times

\footnotetext{
${ }^{48}$ Supra note 5 at 2.

${ }^{49}$ Supra note 41 at 13.

${ }^{50}$ Mountain, 'Law Firm Barriers to Innovation', Law Practice Today, June 2005.
} 
column, Susskind described these 'maverick' lawyers as follows: 'Energetic, often eccentric, frequently marginalised, invariably demanding, singleminded individuals who pursue ideas that are regarded in the early days as peripheral, irrelevant, and even wasteful . . . Mavericks are the research and development departments of many law firms.' ${ }^{51}$

While cultivating internal mavericks is a tricky proposition, successful firms put in place an infrastructure that allows IT projects to move forward when ideas are generated. Probably the single most important difference between the London firms and the U.S. firms is that the London firms have teams of practice support lawyers who do the knowledge management work. They are thus better positioned to experiment with new methods of service delivery. Traditional lawyers do not want to become involved in knowledge management work because it involves large commitments of non-billable time.

\subsection{Inadequate Capitalisation}

Restrictions on outside capital are another barrier to technology-based innovation in law. Typically the incumbents, who have the capital, have little interest in experimenting with disruptive innovations. Restrictions on outside capital protect them to a certain extent from the disruptive attacks of other law firms.

Most U.S. states and Canadian provinces prohibit law firms from having 'layman' equity investors. By way of contrast, the Australian state of New South Wales was among the first jurisdictions in the world to permit multidisciplinary practices ('MDPs') (in 1987) and incorporated practices (in 2001)..$^{52}$

The UK government is in the process of overhauling the regulation of legal services to permit outside investment. The government has relied heavily on academic research provided in a number of commissioned papers. Dow and Lapuerta summarise the problems nicely:

Some large law firms in the United Kingdom have substantial access to capital, but they do not offer the personal legal services that are most susceptible to commoditisation, and they have neither the incentive nor the practical ability to change course. Smaller firms could in theory lead the introduction of more information technology, by signing complex contracts to co-operate with large companies that have access to capital. However, contracts are imperfect instruments for such ventures. Smaller firms could in theory raise their own capital through debt, but there several limitations to raising debt. The problems under

\footnotetext{
${ }^{51}$ Susskind, 'Backroom Boys lead 'positive disruption”, London Times, 15 November 2005.

${ }^{52}$ Mark and Cowdroy, 'Incorporated legal practices -A new era in the provision of legal services in the state of New South Wales', Penn State International Law Review, 22, p. 671 at 673, 674.
} 
the current rules suggest that outside equity is critical for funding the transformation of personal legal services. ${ }^{53}$

The entry of new firms is a principal catalyst for innovation in many industries. To capture market share, new firms must offer something different. Existing firms must respond by matching or exceeding the innovations of the newcomer, or face extinction. Existing firms can be less likely to innovate because they have an interest in protecting the value of their existing franchises ... If ownership restrictions make market entry difficult, existing firms can become complacent, and product quality can suffer. Removing restrictions on ownership could stimulate new entry and innovation in legal services. ${ }^{54}$

The UK is facilitating investment in alternative business structures ('ABSs'), which will be able to provide reserved and unreserved legal and associated non-legal services through a licensing regime. There will be no requirement that lawyers form a majority by number in ABS firms. External investment will be subject to a fitness to own test. ${ }^{55}$

ABSs will improve the climate for innovation in several ways. They will allow huge infusions of capital into law firms, presumably coupled with new ideas for making the practice of law more efficient. The mindset of outside capital will be toward increasing productivity, not generating more billable hours. According to the government's White Paper, one result will be 'the sharing of innovation and technical advances across the professions. ${ }^{56}$ It is not the conventional leaders who generate huge amounts of cash who will be raising money in the capital markets. It is the disruptors, targeting the low end of the legal market initially and moving relentlessly upward.

Deregulation of this sort often precedes rapid change. Over a number of years, all the major New York investment banks gradually converted from partnerships to corporations based in large part on their need to make major investments in information technology. ${ }^{57}$ By 2005, about 60 of 452 incorporated legal practices in New South Wales were multidisciplinary. ${ }^{58}$

\subsection{Rules against Unauthorised Practice}

One big challenge faced by disruptors are the various rules against unauthorised practice of law. In many industries, the incumbents simply ignore disruptors and move upmarket until it is too late. Not so in law. The United

\footnotetext{
${ }^{53}$ Supra note 29 at 10.

${ }^{54}$ Ibid at 12

${ }^{55}$ Department for Constitutional Affairs (UK), 'The Future of Legal Services: putting the Consumer First', October 2005 at 73.

${ }^{56}$ Ibid at 126.

${ }^{57}$ Supra note 41 at 9.

${ }^{58}$ Supra note 55 at 125.
} 
States and Canada have strong traditions of protecting lawyer turf through rules against unauthorised practice. They define the practice of law broadly. Here is a typical definition proposed by the American Bar Association:

The practice of law consists of 'the application of legal principles and judgment with regard to the circumstances or objectives of a person that require the knowledge and skill of a person trained in the law . . ,59

Unauthorised practice covers legal advice but not legal information. The cases have distinguished between simple form filling (legal information) and the interactive advice and documentation that takes into account a user's specific facts and preferences (legal advice). The practice of law has also been held to include advice on selecting forms or categorising documents in certain ways.

In 1999, a district court in Texas held that Quicken Family Lawyer software was engaged in the unauthorised practice of law. The software selected and customised documents based on information prompted from the user. After a public outcry, the Texas State Legislature amended the unauthorised practice of law statute to permit software like Quicken Family Lawyer. ${ }^{60}$

In 2004, We the People agreed to a settlement after being investigated for the unauthorised practice of law in relation to advising customers on when to file for bankruptcy, explaining secured versus unsecured debt, categorising the different types of bankruptcy filings available to a debtor, and distributing how-to books or guides on filing for bankruptcy to customers. ${ }^{61}$

Rules against unauthorised practice protect consumers and are desirable to a certain extent. As Professor Catherine Lanctot asserts, 'an unregulated market in the selling of personalised legal documents could create new problems for consumers if their rights are inadequately protected or even harmed by the documents they receive' ${ }^{62}$ It is a matter of drawing the line 'where consumer protection ends and economic self-protection begins'. ${ }^{63}$

However, Marc Lauritsen believes that, assuming appropriate disclaimers, legal software deserves the same treatment as legal books and other written materials:

Computer programs by definition are incapable of 'judgment', since they always give the same pre-ordained answer to the same question. Absent a human contemporaneously in the loop who can exercise

\footnotetext{
${ }^{59}$ American Bar Association Task Force on the Model Definition of the Practice of Law, Proposed Model Definition of the Practice of Law, § (b) (1), 18 September 2002.

${ }^{60}$ Lanctot, 'Scriveners in Cyberspace', Hofstra Law Review 30, p. 811 at 836.

${ }^{61}$ Bobelian, 'We the People Pledges to Avoid Unauthorized Practice of Law', New York Law Journal, 13 May 2005.

${ }^{62}$ Supra note 60 at 848 .

${ }^{63}$ Ibid at 821.
} 
'judgment,' the programmed logic of a document assembly program should be treated no differently than the same thing written out in the pages of a book. [Does the software need to start saying IANAH (I am not a human)?] ${ }^{64}$

Balanced against the rules banning unauthorised practice are the constitutional right to free speech and competition and antitrust law. In the United States, the Federal Trade Commission has criticised the ABA's proposed definition of unauthorised practice as being too restrictive. ${ }^{65}$

The UK system is more relaxed and open to disruptive models than the U.S. It minimises regulation in several low end categories where disruptive pressure is likely to arise and creates vertical areas of competency whereby specialist non-lawyers are permitted to provide a limited range of legal services.

The UK divides legal services into reserved and non-reserved categories and protects only the latter. Reserved services require certification with specified regulatory bodies and include the right to litigate, rights of audience, immigration, probate, conveyancing, notarial services, and acting as a commissioner of oaths. Licensed conveyancers, notaries, legal executives, and patent and trademark attorneys can provide reserved services in addition to lawyers. Unreserved services include general legal advice, will drafting, employment advice, and claims management (although claims management is in the process of being shifted to a reserved service) ${ }^{66}$ Unreserved services will be subject to the oversight and regulation of the proposed new regulator.

Other rules that hamper disruption are rules that restrict referral fees, restrictions on employed solicitors acting for third parties, ${ }^{67}$ and rules that prohibit the sharing of fees with non-lawyers. ${ }^{68}$ The UK is removing these types of rules to allow organisations such as banks and insurers to provide legal services directly to the public. In that respect, Australia's eCommLegal Pty Ltd., referred to earlier, provides an example of things to come.

\section{The Future}

If there is a 'disruptive technology' in law in the sense that Christensen once used the term, it is online document assembly. As we reflect on the spectrum of business models, it is clear that the future of document

\footnotetext{
${ }^{64}$ Lauritsen, 'Ethics, UPL, and online document automation: Informal session notes for the 2006 Equal Justice Conference' at 2.

${ }^{65}$ Federal Trade Commission letter to American Bar Association Task Force, December 20, 2002.

${ }^{66}$ Supra note 55 at 14.

${ }^{67}$ Supra note 55 at 118.

${ }^{68}$ See for example, Law Society of British Columbia, Professional Conduct Handbook Chapter 9 Rule 6 http://www.lawsociety.bc.ca/publications_forms/handbook/handbook_toc.html
} 


\section{Sustaining and disruptive business models that use document assembly technology}

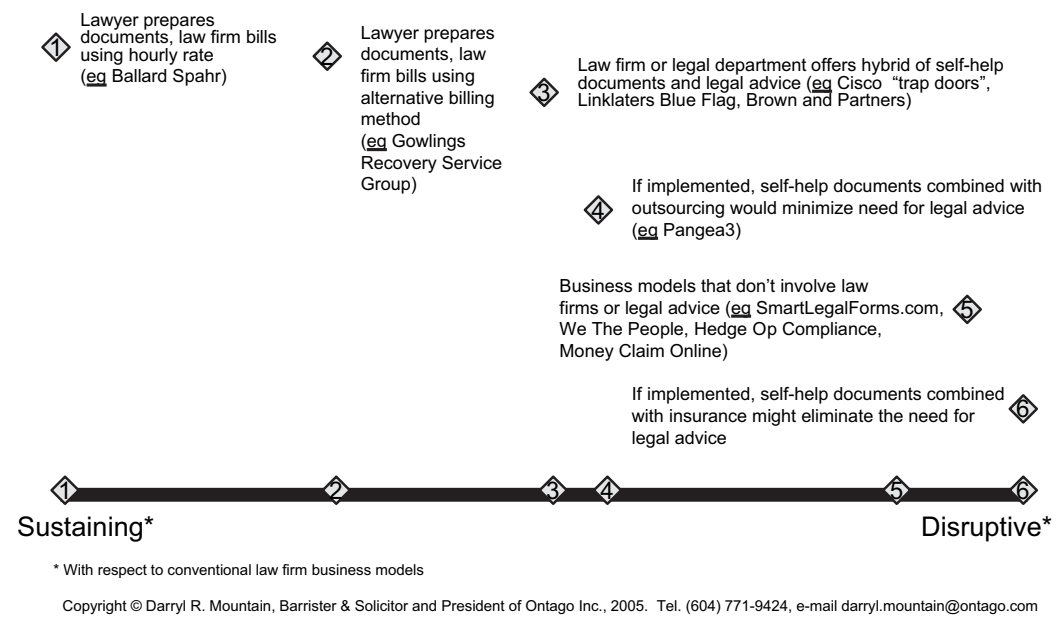

assembly is on the disruptive side of the equation. Business models that combine document assembly with other innovations will continue to make a wide spectrum of legal services available to the consumer. These business models will be launched by law firms, multidisciplinary practices, banks, supermarkets, insurance companies, dot-coms, in-house legal departments, and legal process outsourcing companies. Some will offer a full spectrum of services, from the sustaining to the disruptive. Others will focus on particular niches.

As for the barriers, they will continue to fall, albeit slowly. Brad Gambill of Innosight puts it this way:

Every situation I've studied or been involved in has similarly daunting barriers. These can never be changed or overcome all at once and en masse. They are typically continually eroded at the margin by firms willing to push the envelope a little until they are gone. In my experience, disruption really begins to take hold when you have lots of little 'nibblers' eroding the barriers simultaneously. To me, it feels like the legal industry has these sorts of situations in many spaces. ${ }^{69}$

The progress will be the quickest in those jurisdictions that are the most flexible with respect to rules against unauthorised practice and restrictions on outside capital. Perhaps document assembly will at long last fulfill its promise of being to the law what spreadsheets are to accounting.

\footnotetext{
${ }^{69}$ Personal e-mail from Brad Gambill, of Innosight LLC, 23 April 2006.
} 


\section{References}

American Bar Association Legal Technology Resource Center, '2004-2005 American Bar Association Legal Technology Survey Report: Law Office Technology' (2005) http://www.lawtechnology.org/survstat.html

American Bar Association Task Force on the Model Definition of the Practice of Law, Proposed Model Definition of the Practice of Law, § (b) (1), 18 September 2002.

Anderson, Chris, The Long Tail: Why the Future of Business is Selling Less of More (Hyperion: New York 2006).

Bobelian, Michael, 'We The People Pledges to Avoid Unauthorized Practice of Law', New York Law Journal, 13 May 2005. http://www.law.com/jsp/article. jsp?id=1115888710371

Brealey, Richard A. and Julian R. Franks, 'The Organisational Structure of Legal Firms; a Discussion of the Recommendations of the 2004 Review of the Regulatory Framework for Legal Services in England and Wales', 13 July 2005. http://www.dca.gov.uk/legalsys/lsreform.htm

Christensen, Clayton M., The Innovator's Dilemma: When New Technologies Cause Great Firms to Fail (Harvard Business School Press: Boston 1997).

Christensen, Clayton M. and Michael E. Raynor, The Innovator's Solution: Creating and Sustaining Successful Growth (Harvard Business School Press: Boston 2003).

Christensen, Clayton M., Scott D. Anthony and Erik A. Roth, Seeing What's Next: Using the Theories of Innovation to Predict Industry Change (Harvard Business School Press: Boston 2004).

Department for Constitutional Affairs (UK), 'The Future of Legal Services: putting the Consumer First', October 2005. http://www.dca.gov.uk/legalsys/ lsreform.htm

Dow, James and Carlos Lapuerta, 'The Benefits of Multiple Ownership Models in Legal Services', July 2005. http://www.dca.gov.uk/legalsys/lsreform.htm

Federal Trade Commission letter to American Bar Association Task Force, December 20, 2002. http://www.ftc.gov/opa/2002/12/lettertoaba.htm

Fishman, Ted, China Inc.: How the Rise of the Next Superpower Challenges America and the World (Scribner: New York 2005).

Galanter, Marc and Thomas Palay, 'The Many Futures of the Big Law Firm', South Carolina Law Review, (1994), 45, p. 905.

Granat, Richard, Camille Cameron and Anand Subramanian, 'Partners and Promise in E-Lawyering', ABA TECHSHOW 2006, 20 April 2006.

Granat, Richard, Marc Lauritsen and Darryl R. Mountain, 'Will Document Automation Disrupt the Legal Profession? A roundtable discussion sponsored by the ABA's eLawyering Task Force', Loew's Hotel Philadelphia, 22 October 2005.

Innosight LLC, 'eLawForum: Transforming Legal Services', 21 January 2003, Research Paper available at http://www.innosight.com.

Janis, Blair, Richard Granat and Lisa Colpoys, 'Ten Techniques to Exploit Latent Legal Markets', ABA TECHSHOW 2006, 20 April 2006.

Lanctot, Catherine J., 'Scriveners in Cyberspace', Hofstra Law Review (2002), 30, p. 811. http://www.hofstra.edu/PDF/law_lanctot.pdf

Lauritsen, Marc, 'Ethics, UPL, and online document automation: Informal session notes for the 2006 Equal Justice Conference', 2006, unpublished. 
Lauritsen, Marc, 'Fall in line with document assembly: applications to change the way you practice', Law Office Computing, February/March 2006, p. 70. http:// www.capstonepractice.com/loc2006.pdf

Lauritsen, Marc, 'It's About Time', Law Practice Management, April 2002, p. 26. http://www.capstonepractice.com/abouttime.pdf.

Lauritsen, Marc, 'Profit more by billing less: technology that saves time and fattens the bottom line', TechnoLawyer, 21 February 2006.

Law Society of British Columbia, Professional Conduct Handbook Chapter 9 Rule 6. http://www.lawsociety.bc.ca/publications_forms/handbook/handbook_toc.html

Mark, Steven and Georgina Cowdroy, 'Incorporated legal practices -A new era in the provision of legal services in the state of New South Wales', Penn State International Law Review, 2004, 22, p. 671. www.lawcouncil.asn.au/shared/ 2418152669.pdf

Mountain, Darryl R., 'Could new technologies cause great law firms to fail?', 2001 (1) The Journal of Information, Law and Technology (IILT). http://www2.warwick. ac.uk/fac/soc/law/elj/jilt/2001_1/mountain/

Mountain, Darryl R., 'Law Firm Barriers to Innovation', Law Practice Today, June 2005. http://www.abanet.org/lpm/lpt/articles/tch06053.html

Owen, Laura, 'The Tech Evolution: Change or Die', Law.com, 4 January 2005. http://www.law.com/jsp/ltn/pubArticleLTN.jsp?id=1104759335187

Saunders, Doug, 'Why you don't have a robot maid' Globe and Mail (Toronto), 11 February 2006, F3.

Susskind, Richard E., The Future of Law: Facing the Challenges of Information Technology (Clarendon Press: Oxford 1996).

Susskind, Richard E., 'Backroom Boys lead 'positive disruption', London Times, 15 November 2005. <http://www.timesonline.co.uk/article/0,200-1869103,00.html>

Susskind, Richard E., 'The Next Ten Years', Society for Computers and Law 2006 Annual Lecture, 6 March 2006 http://brightsite.bright-talk.com/mod/ event\&op=view\&guid=047648519302e383

Warner Bros. Records, “Confessions On A Dance Floor': New Madonna Album Re-Invents Dance Music for a New Generation', October 12, 2005. http:// $\underline{\text { www.marketwire.com/mw/release_html_b1?release_id }=97678}$ 